\title{
Specific Detection of Cherry Mottle Leaf Virus Using Digoxigenin-Labeled cDNA Probes and RT-PCR
}

D. James, Centre for Plant Health, Canadian Food Inspection Agency, 8801 East Saanich Road, Sidney, B.C., Canada, V8L 1H3; W. Jelkmann, Biologische Bundesanstalt fur Land- Und Forstwirtschaft, Institut fur Pflanzenschutz im Obstbau, D-69221 Dossenheim, Germany; and C. Upton, Department of Biochemistry and Microbiology, University of Victoria, B.C., Canada, V8W 3P6

\begin{abstract}
James, D., Jelkmann, W., and Upton, C. 1999. Specific detection of cherry mottle leaf virus using digoxigenin-labeled cDNA probes and RT-PCR. Plant Dis. 83:235-239.

Cherry mottle leaf virus (CMLV)-associated double-stranded RNA (dsRNA) was isolated from the propagation host Chenopodium quinoa. The dsRNA band, with a molecular weight estimated at $7.0 \times 10^{6} \mathrm{Da}$, was used to produce cDNA. Two recombinant plasmids from the cloned cDNA library were identified that specifically bound with CMLV-associated RNA in dot blot hybridization studies. The cDNA inserts were sequenced, and oligonucleotide primers were designed that specifically amplify an 848-bp fragment of the CMLV genome by reverse-transcription polymerase chain reaction. Also, a poly $(\mathrm{T})$ primer was reliably used for reverse transcription, with specific amplification using the CMLV primers, suggesting polyadenylation of the virus genome. Search of the database revealed some sequence homology of the partially characterized genome of CMLV with that of apple chlorotic leafspot virus. Additional sequence data are required, however, to establish the taxonomic position of the filamentous CMLV.
\end{abstract}

The causal agent of cherry mottle leaf disease was identified as a filamentous virus with a length of $760 \mathrm{~nm}$, width of $10.2 \mathrm{~nm}$, and striations $3.1 \mathrm{~nm}$ in pitch $(7,10)$. The subunit size of cherry mottle leaf virus (CMLV) capsid protein is estimated at 20.5 $\mathrm{kDa}$ (6). Polyclonal and monoclonal antibodies have been developed against this virus and have been used for serological detection of the virus (11). The CMLV-associated antibodies were observed to crossreact with peach mosaic disease-associated virus (PMV) $(8,9)$. Oldfield et al. (18) was able, therefore, to use antibodies developed against CMLV in a survey for PMV. All isolates of PMV tested cross-reacted with CMLV-associated antibodies, both polyclonal and monoclonal $(9,18)$. Two viruses infecting Prunus spp. are known to be transmitted by eriophyid mites, PMV (by Eriophyes insidiosus Kiefer \& Wilson [13]), and CMLV (by E. inaequalis Wilson \& Oldfield [17]). The two viruses are very similar, having filamentous morphology, similar sizes, identical coat protein subunit sizes, and identical double-stranded RNA (dsRNA) profiles $(9,10,18)$. The two viruses are closely related and may be strains of the

Corresponding author: D. James

E-mail: jamesd@em.agr.ca

Accepted for publication 30 October 1998.

Publication no. D-1998-1214-05R

This article is in the public domain and not copyrightable. It may be freely reprinted with customary crediting of the source. The American Phytopathological Society, 1999. same virus. They differ in host range and symptomatology, and cause distinct diseases, but they share some common hosts. It is essential, therefore, to develop a reliable diagnostic technique capable of distinguishing these two viruses, especially in their common hosts. This is necessary for effective control of the associated diseases.

Nucleic acid-based techniques are generally more sensitive and can be designed to be more specific than detection procedures using serology. Certain nucleic acidbased techniques have the potential to detect single nucleotide differences and may be useful in distinguishing different strains of a virus (15). Differentiation of strains of soybean mosaic virus was accomplished using RNA sequence-specific oligonucleotide primers for reverse-transcription polymerase chain reaction (RTPCR) (20). Other more complex nucleic acid-based procedures have been used to distinguish virus strains or isolates; for example, RT-PCR has been combined with restriction fragment length polymorphism (22,26); also, heminested-PCR and PCR enzyme-linked immunosorbent assay (PCR-ELISA) $(19,21)$ have been used. In this study, dsRNA was used as a template for cDNA production, and dot blot hybridization was used to identify virus-specific cDNA clones, which were then sequenced. This information was then used to design oligonucleotide primers for the specific detection of CMLV by RT-PCR.

\section{MATERIALS AND METHODS}

Virus sources. CMLV isolate Sa116221 was maintained in Prunus avium var.
Bing and in the propagation host Chenopodium quinoa. CMLV isolate Sa1162-22 was maintained in Bing cherry. CMLV isolates 1819-03 (P002) in peach and 181911 (SC21) in sweet cherry were obtained from L. Parish, Wenatchee, Washington. These two isolates were tested as dormant wood samples. Isolates C27-4B, SP4-14 (provided by T. Li, Pacific Agricultural Research Centre, Agriculture and AgriFood Canada) and CMLAE-88-15 and BCAE-89-7 (provided by J. Uyemoto and G. Oldfield, USDA, University of California, Davis and Riverside, respectively) were freeze-dried infected cherry leaf samples. The peach mosaic isolates CA-1, CA2, CA-3, CA-4, and CO-2 (CL-2) were obtained from H. J. Larsen (Agricultural Experiment Station, Colorado State University, Colorado) and used as freeze-dried samples of infected peach leaves.

Isolation of CMLV-associated dsRNA. Seedlings of $C$. quinoa were rub-inoculated with CMLV isolate Sa1162-21, and symptomatic leaves were collected 10 to 12 days postinoculation. dsRNA extraction was carried out on the freshly collected leaves or on leaves stored at $-80^{\circ} \mathrm{C}$. Twenty g of infected $C$. quinoa leaves was ground to a powder in liquid nitrogen, and the dsRNA was extracted using a procedure based on that of Morris and Dodds (16) The dsRNA solution was treated with RNase T1 (10 $\left.\mathrm{U} \mathrm{ml}^{-1}\right)$ for $30 \mathrm{~min}$, adjusted to $30 \mathrm{mM} \mathrm{MgCl}_{2}$, treated with $10 \mu \mathrm{g} \mathrm{ml}^{-1}$ DNase for $30 \mathrm{~min}$, and subjected to a second cycle of CF11 purification. The dsRNA was collected by ethanol precipitation, and the samples were analyzed by agarose gel electrophoresis with ethidium bromide staining.

Synthesis of cDNA. The CMLV-associated dsRNA band with an estimated molecular weight of $7.0 \times 10^{6} \mathrm{Da}$, presumably representing the entire virus genome (9), was isolated by electrophoresis using low melt preparative grade agarose (Bio-Rad, Mississauga, Ontario). The target dsRNA was recovered using phenol-chloroform extraction and ethanol-sodium acetate precipitation. The purified dsRNA was resuspended in diethylpyrocarbonate-treated sterile double distilled water $\left(\operatorname{depc} \mathrm{H}_{2} \mathrm{O}\right)$ and denatured by treatment with methylmercuric hydroxide (MeHg) (12). Synthesis of cDNA was carried out as described by Jelkmann et al. (12). The double- 
stranded cDNA was recovered by phenol extraction with subsequent sepharose CL4B column purification and ethanol precipitation.

cDNA cloning and sequencing. The cDNA was blunt end ligated into the EcoRV site of pBluescript II KS (+) plasmids (Stratagene, PDI BioScience, Aurora, Ontario) and used to transform Escherichia coli cells (MAX Efficiency DH5 $\propto$, Gibco/BRL, Burlington, Ontario). Ampicillin screening and blue/white selection were used to select transformed $E$. coli containing recombinant plasmids. To identify colonies with plasmids containing virus-derived cDNA inserts, the library was screened by colony filter hybridization (4) using ${ }^{32} \mathrm{P}$-labeled cDNA probes. The probes were produced by reverse transcription of gel purified high molecular weight CMLV-associated dsRNA, using random primers (23).

Denatured dsDNA was sequenced using Applied Biosystem's (ABI) Model 373 Stretch with ABI's enzyme Sequenase Version 2.0, a modified T7 DNA polymerase. Since the cDNAs were ligated into pBluescript, sequencing of the cDNA clones was carried out using $\mathrm{T} 7$ and $\mathrm{T} 3$ primers as described by the suppliers. $\mathrm{Nu}$ cleotide sequence data were compiled and analyzed using the GCG program package ver. Unix-7.3 (1) and database searches of the National Center for Biotechnology Information (NCBI, National Institutes of
Health) and Heidelberg Unix Sequence Analysis Resources (HUSAR 3.0) (German Cancer Research Centre, Heidelberg, Germany).

Total RNA extraction and dot blot hybridization. Total RNA was extracted from healthy and infected leaf tissue (100 mg) using the Qiagen Rneasy Total RNA kit, following the directions provided by the supplier (Qiagen, Chatsworth, CA). The total RNA was eluted with $30 \mu \mathrm{l}$ depc $\mathrm{H}_{2} \mathrm{O}$ into sterile RNase-free microfuge tubes. Samples of total RNA were denatured by treatment with formaldehyde and incubation at $60^{\circ} \mathrm{C}$ for $30 \mathrm{~min}(25)$. The denatured samples were placed on ice for 5 min, then applied to Bio-Rad's Zeta-Probe blotting membranes. The membranes were soaked in sterile double distilled $\mathrm{H}_{2} \mathrm{O}$ for 5 min and soaked twice, 5 min each time, in $20 \times$ SSC $($ SSC $=0.15 \mathrm{M}$ sodium chloride and $0.015 \mathrm{M}$ trisodium citrate, $\mathrm{pH}$ 7.0) prior to blotting. The membranes were airdried, and the RNA was bound to the membrane by baking in a vacuum oven for $2 \mathrm{~h}$ at $80^{\circ} \mathrm{C}$.

The plasmids pCML4, pCML10, and pCML13 were cloned in E. coli MAX Efficiency DH5 $\propto$ competent cells (Gibco/ BRL) and purified using Bio-Rad's Plasmid Miniprep Kit (Quantum Prep) following the instructions provided by the supplier. The cDNA insets were excised with the restriction enzymes $X b a \mathrm{I}$ and $X h o I$, then gel purified. Digoxigenin la- beling of the inserts was carried out using Boehringer Mannheim's Dig DNA Labeling and Detection Kit. These probes were used to screen membranes spotted with total RNA extracts.

Membranes with total RNA affixed were placed in sealed hybridization bottles $(\mathrm{BH}-$ 9004, BIO/CAN Scientific, Mississauga, Ontario) containing $10 \mathrm{ml}$ of prehybridization mixture $(6 \times$ SSC, $5 \times$ Denhardt's solution, $0.5 \%$ sodium dodecyl sulfate [SDS], $100 \mu \mathrm{g}$ of denatured salmon sperm DNA per $\mathrm{ml}$, and $50 \%$ formamide). Prehybridization was carried out in a TEK*STAR JR Hybridization oven (BIO/CAN) set at $42^{\circ} \mathrm{C}$, for $16 \mathrm{~h}$. The DIG-labeled probe was denatured by heating at $98^{\circ} \mathrm{C}$ for $5 \mathrm{~min}$, then added to $5 \mathrm{ml}$ of fresh prehybridization buffer, which was then used to probe the membranes. Hybridization was carried out at $42^{\circ} \mathrm{C}$ for $24 \mathrm{~h}$. The membranes were washed four times, $5 \mathrm{~min}$ each, at room temperature with $2 \times \mathrm{SSC}, 0.1 \%$ SDS (wt/vol), and twice for $5 \mathrm{~min}$ at $50^{\circ} \mathrm{C}$ with $0.1 \times$ SSC, $0.1 \%$ SDS (wt/vol), $1 \mathrm{mM}$ EDTA. Colorimetric detection using antidigoxigenin Fab-fragments conjugated to alkaline phosphatase was carried out using the procedure described by the supplier (Boehringer Mannheim).

RT-PCR. PCR was carried out in a RoboCycler 40 Temperature Cycler with a Hot Top Assembly attached (Stratagene, la Jolla, CA), using sterile $0.5-\mathrm{ml}$ microfuge tubes. The upstream primer (CML13A)

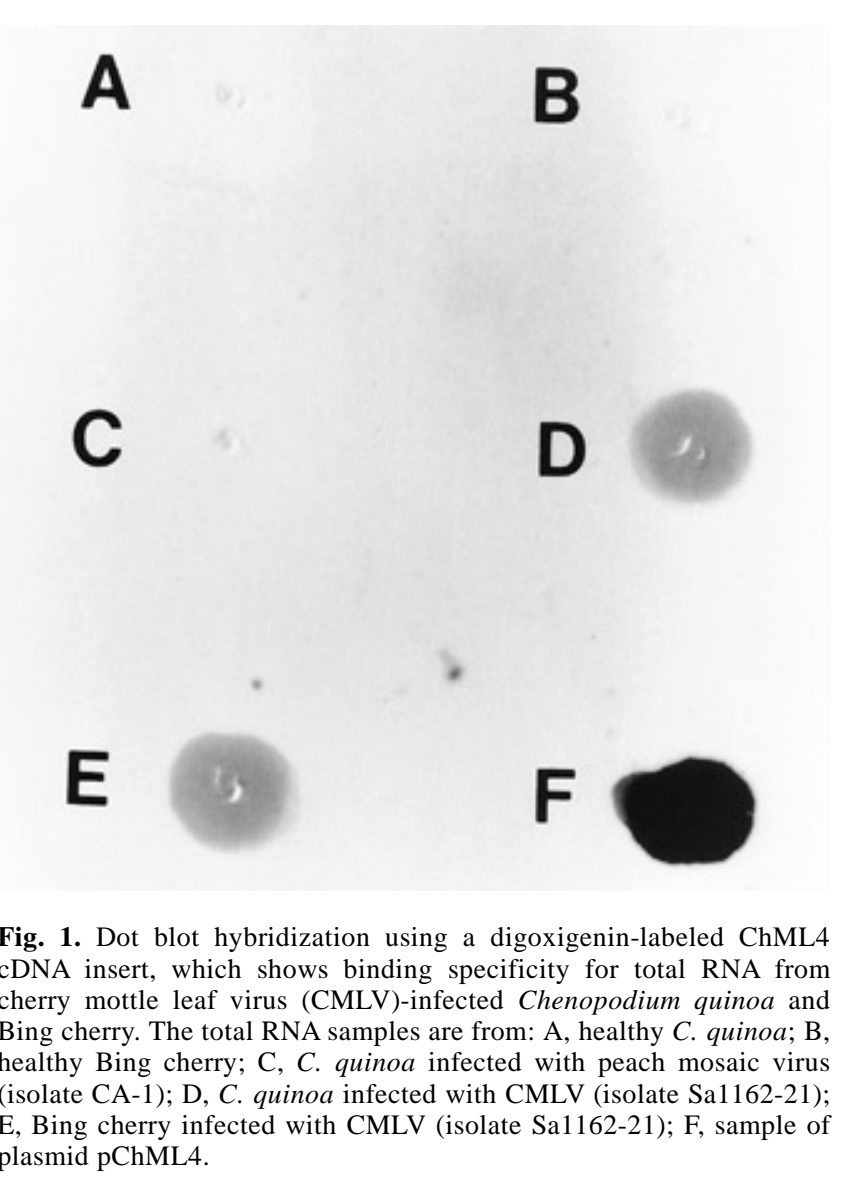

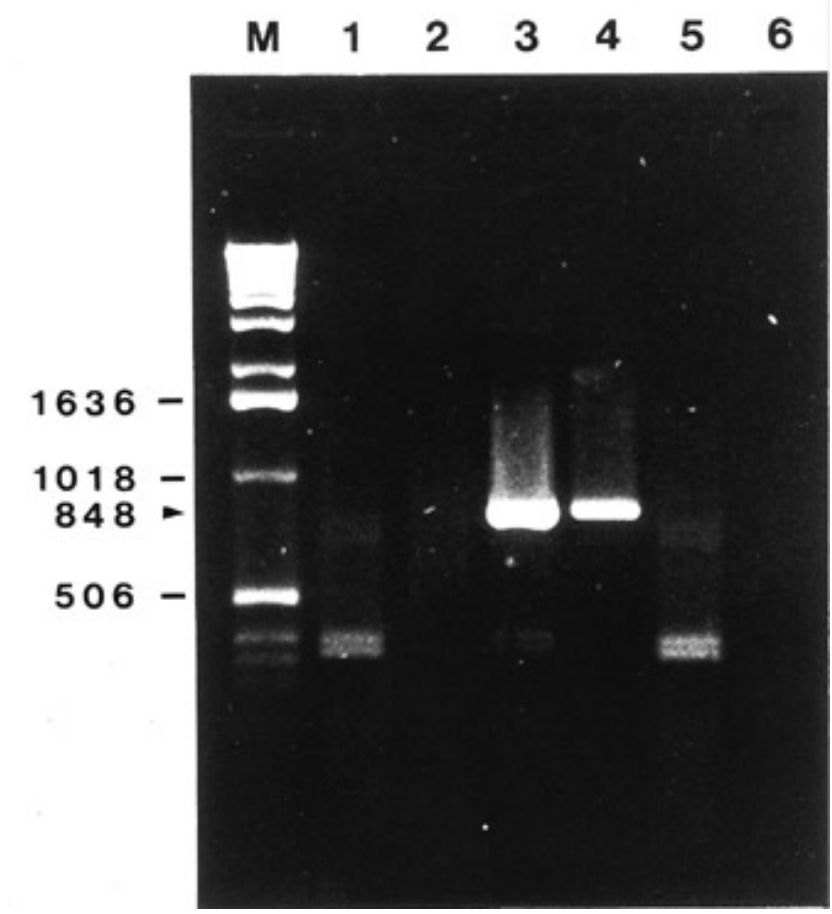

Fig. 2. Specific detection of cherry mottle leaf virus (CMLV) by reverse transcription-polymerase chain reaction analysis of total RNA extracts using primers CML4A and CML13A, which amplify an 848-bp product. Lane M, 1-kb DNA ladder; lane 1, healthy Chenopodium quinoa; lane 2, healthy Bing cherry; lane 3, C. quinoa infected with CMLV (isolate Sa1162-21); lane 4, Bing cherry infected with CMLV (isolate Sa116221); lane 5, C. quinoa infected with peach mosaic virus (PMV, isolate CA-1); lane 6, peach infected with PMV (isolate CA-1). 
sequence was 5'-GCCTGATCAGCAAAGTGAAG-3' (20 nt), and the downstream primer (CML4A) sequence was 5'CGGTCTGAAGCACAATGC-3' (18 nt). Initially, optimization of the PCR conditions was carried out. The following conditions were assessed: number of cycles $(25,28,30$, and 35$)$; annealing temperature $\left(55,58,60,61\right.$, and $\left.62^{\circ} \mathrm{C}\right)$; primer concentration $(3.5,7,14$, and 21 pmoles); dNTP concentration $(0.125 \mathrm{mM}, 0.25 \mathrm{mM}, 0.5$ $\mathrm{mM}$, and $0.75 \mathrm{mM}$ ); and $\mathrm{MgCl}_{2}$ concentration $(0.5 \mathrm{mM}, 1 \mathrm{mM}, 1.5 \mathrm{mM}$, and 2 $\mathrm{mM})$. RT was carried out in a total reaction volume of $20 \mu \mathrm{l}$. Approximately 2 to $4 \mu \mathrm{g}$ of total RNA in $5 \mu$ depc $\mathrm{H}_{2} \mathrm{O}$ was combined with $2 \mu \mathrm{l}(7 \mathrm{pmol})$ primer CML4A and incubated at $75^{\circ} \mathrm{C}$ for $5 \mathrm{~min}$. This was followed by the addition of $13 \mu \mathrm{l}$ of RT reaction mix ( $4 \mu \mathrm{l}$ of $5 \times$ First strand buffer [Gibco/BRL], $2 \mu \mathrm{l}$ of $0.1 \mathrm{M}$ DTT, $0.5 \mu \mathrm{l}$ of $10 \mathrm{mM}$ dNTP mix, $0.25 \mu \mathrm{l}$ of RNase inhibitor, $0.5 \mu \mathrm{l}$ of Superscript II [Gibco/ BRL], and the volume adjusted to $13 \mu \mathrm{l}$ with depc $\mathrm{H}_{2} \mathrm{O}$ ). RT was carried out at $42^{\circ} \mathrm{C}$ for $45 \mathrm{~min}$. Following RT, $80 \mu \mathrm{l}$ of PCR mix $(0.5 \mu \mathrm{l}$ of $10 \mathrm{mM}$ dNTP, $3 \mu \mathrm{l}$ of $50 \mathrm{mM} \mathrm{MgCl} 2,2 \mu \mathrm{l}[7 \mathrm{pmol}]$ of primer CML13A, $2 \mu \mathrm{l}$ [7 pmol] of primer CML4A, $1 \mu \mathrm{l}$ of Taq DNA polymerase [Gibco/BRL], $1 \mu \mathrm{l}$ of Taq Extender PCR Additive [Stratagene], $10 \mu \mathrm{l}$ of $10 \times \mathrm{Taq}$ Extender buffer, and depc $\mathrm{H}_{2} \mathrm{O}$ to obtain final volume) was added to each tube. The samples were incubated in a Stratagene Robocycler using a program of 30 cycles of denaturation, annealing, and extension $\left(94^{\circ} \mathrm{C}\right.$ for $30 \mathrm{~s}, 60^{\circ} \mathrm{C}$ for $45 \mathrm{~s}$, and $72^{\circ} \mathrm{C}$ for $1 \mathrm{~min}$, respectively) followed by a $10-\mathrm{min}$ extension step at $72^{\circ} \mathrm{C}$. After RT-PCR, 10$\mu \mathrm{l}$ samples of the reaction products were analyzed by electrophoresis on a $1 \%$ agarose gel stained with ethidium bromide.

In a related study, a poly( $\mathrm{T})$ primer was used for reverse transcription with subsequent PCR amplification using the primers CML4A and CML13A to determine if the virus was polyadenylated at the $3^{\prime}$ end. Total RNA extracted from healthy $C$. quinoa and from $C$. quinoa infected with either CMLV or PMV were used.

Immunocapture RT-PCR. In immunocapture RT-PCR (IC/RT-PCR), $100 \mu \mathrm{l}$ of ammonium sulfate-purified CMLV polyclonal antibody or peach mosaic virus (PMV) polyclonal antibody (approximately $2 \mu \mathrm{g} / \mathrm{ml}$, diluted $1: 100$ ) was added to $0.5-$ $\mathrm{ml}$ microcentrifuge tubes and incubated at $37^{\circ} \mathrm{C}$ for $3 \mathrm{~h}$. The tubes were washed two times with $150 \mu \mathrm{l}$ of phosphate buffered saline with $0.05 \%$ Tween 20 . Healthy and infected tissue were triturated in $0.01 \mathrm{M}$ phosphate buffer containing $0.02 \mathrm{M}$ diethyldithiocarbamic acid, sodium salt; $0.04 \mathrm{M}$ sodium thioglycolate; and $0.5 \%$ nicotine. The samples were centrifuged at 5,000 $\times g$ for $10 \mathrm{~min}$, and the clarified supernatant was collected. One hundred $\mu \mathrm{l}$ of the clarified extract was added to each antibodycoated tube and incubated overnight at $4^{\circ} \mathrm{C}$. The tubes were washed as described above, and $20 \mu \mathrm{l}$ of RT mix was added to each tube (RT mix: $4 \mu$ of $5 \times$ first strand buffer [Gibco/BRL], $2 \mu$ of 0.1 M DTT, $0.5 \mu \mathrm{l}$ of $10 \mathrm{mM}$ dNTPs, $0.25 \mu \mathrm{l}$ of RNase inhibitor, $0.5 \mu \mathrm{l}$ of SUPERSCRIPT II [Gibco/BRL], $1 \mu \mathrm{l}$ of CML4A primer [2 pmol], $2.4 \mu \mathrm{l}$ of $1.7 \%$ Triton-X, and made up to volume with depc $\mathrm{H}_{2} \mathrm{O}$ ). The tubes were vortexed, centrifuged briefly, and incubated at $42^{\circ} \mathrm{C}$ for $45 \mathrm{~min}$, and at $99^{\circ} \mathrm{C}$ for $5 \mathrm{~min}$. After RT, $80 \mu \mathrm{l}$ of PCR mix (see RT-PCR) was added, and the PCR reaction was carried out as described above for RTPCR.

Tube capture RT-PCR. In tube capture RT-PCR (TC/RT-PCR), no antibodies were used to trap the virus targets. The healthy and infected tissue samples were triturated and centrifuged as described for IC/RT-PCR, and $100 \mu \mathrm{l}$ of the clarified sap was added directly to each $0.5-\mathrm{ml}$ microfuge tube. The rest of the procedure was carried out exactly as described for IC/RT-PCR.

\section{RESULTS}

cDNA synthesis and dot blot hybridization. A library of 19 cDNA clones, with inserts ranging in size from 300 to 1,200 $\mathrm{bp}$, was selected after colony filter hybridization and restriction enzyme analysis. Clones pCML4, pCML10, and pCML13 were digoxigenin-labeled and used in dot blot hybridization assays to assess specificity. Probes CML4 and CML13 specifically hybridized with total RNA extracted from symptomatic leaves of $C$. quinoa and Bing cherry infected with CMLV isolate Sa1162-21. Figure 1 shows the specific binding of probe CML4 with CMLV-associated RNA in dot blot hybridization. These probes also hybridized with denatured CMLV-associated dsRNA. Probe specificity was confirmed by the absence of any hybridization signal, either with samples of total RNA from healthy control plants, or from plants infected with peach mosaic virus (isolate CA-1) (Fig. 1). Probe CML10 hybridized with a sample of the original plasmid from which it was derived; no significant reaction was observed with either total RNA from the healthy controls or total RNA from any of the infected tissue.

Selection of primer pairs and optimization of RT-PCR. Using sequence information derived from clones that specifically hybridized with total RNA samples from CMLV-infected tissue, a number of primers were designed and tested for the specific detection of CMLV by RT-PCR. The most suitable primers were the upstream primer CML13A (5'-GCCTGATCAGCAAAGTGAAG-3' (20 nt) and the downstream primer CML4A (5'-CGGTCTGAAGCACAATGC-3') (18 nt). These primers specifically amplify an 848-bp fragment of the CMLV genome. Successful amplification was achieved over a range of conditions. The optimal conditions, giving a well-amplified product in herbaceous and woody hosts with minimal background, consisted of the following: $7 \mathrm{pmol}$ of each primer, 1.5 $\mathrm{mM} \mathrm{MgCl}_{2}, \quad 0.25 \mathrm{mM}$ dNTP, $60^{\circ} \mathrm{C}$ annealing temperature, and 30 cycles.

PCR detection. The primer pair CML4A and CML13A was used in RTPCR to specifically detect CMLV in both C. quinoa and Bing cherry (Fig. 2). All isolates of CMLV tested (Table 1) were successfully detected by RT-PCR using total RNA extracts, or by immunocapture RT-PCR. Figure 3 shows detection of six of these isolates by immunocapture RTPCR. CMLV isolates 1819-03 and 1819-11 were detected using dormant wood tissue. The size of the amplified cDNA fragment in all cases was $848 \mathrm{bp}$, as expected. This amplified product was not observed for PCR analysis of healthy control plants or for herbaceous or woody plants infected with any of the PMV isolates tested (Table 1, Figs. 2 and 3).

The amplified cDNA fragment, $848 \mathrm{bp}$ in size, was also obtained consistently when the poly $(\mathrm{T})$ primer was used for RT and the primers CML4A and CML13A were used for PCR. Amplification of this product was not observed with the healthy controls or PMV-infected samples.

RT-PCR detection was compared with dot blot hybridization for the detection

Table 1. Results of reverse transcription-polymerase chain reaction (RT-PCR) analysis of isolates of cherry mottle leaf virus (CMLV) and peach mosaic virus (PMV) using the primers CML4A and CML13A

\begin{tabular}{llllc}
\hline Virus & Isolate & Host & Origin & RT-PCR result \\
\hline CMLV & Sa1162-21 & Cherry & Sidney, B.C. & + \\
& Sa1162-22 & Cherry & Sidney, B.C. & + \\
& 1819-03(P002) & Peach & Wenatchee, WA & + \\
& $1819-11($ SC21) & Cherry & Wenatchee, WA & + \\
C27-4B & Cherry & Summerland, B.C. & + \\
& SP4-14 & Cherry & Summerland, B.C. & + \\
CMLAE-88-15 & Cherry & California & + \\
& BCAE-89-7 & Cherry & California & + \\
PMV & CA-1 & Peach & San Bernardino, CA & - \\
& CA-2 & Peach & Riverside, CA & - \\
& CA-3 & Nectarine & El Centro, CA & - \\
& CA-4 & Peach & Riverside, CA & - \\
& CO-2(CL-2) & Peach and apricot & Colorado & - \\
\hline
\end{tabular}




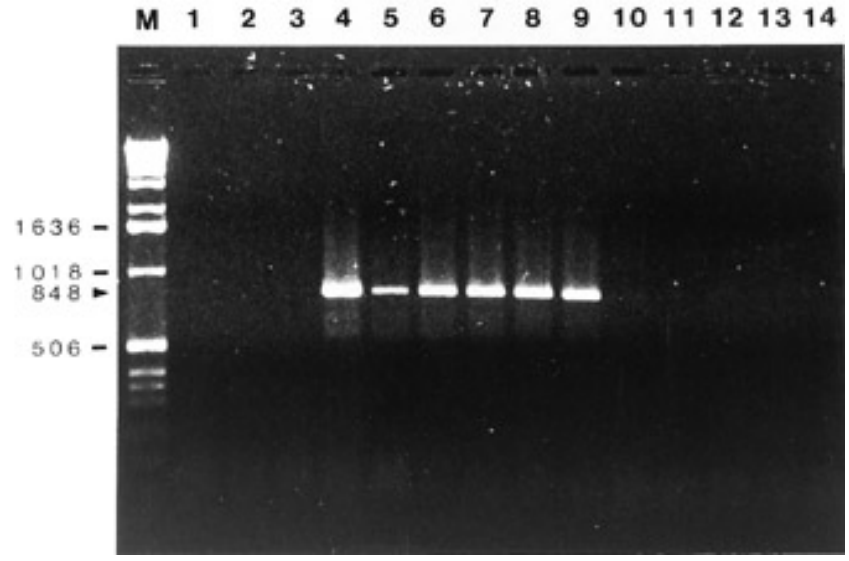

Fig. 3. Specific detection of several isolates of cherry mottle leaf virus (CMLV) by immunocapture reverse transcription-polymerase chain reaction using CMLV polyclonal antibody and the primers CML4A and CML13A. Lane M, 1-kb DNA ladder; lane 1, healthy Chenopodium quinoa; lane 2, healthy Bing cherry; lane 3, healthy Elberta peach; lane 4, C. quinoa infected with CMLV (isolate Sa1162-21); lanes 5 to 9, cherry infected with isolates Sa1162-22, CMLAE-88-15, BCAE-89-7, C274B, and SP4-14, respectively; lanes 10 to 14 , peach infected with peach mosaic virus isolates CA-1, CA-2, CA-3, CA-4, and CO-2.

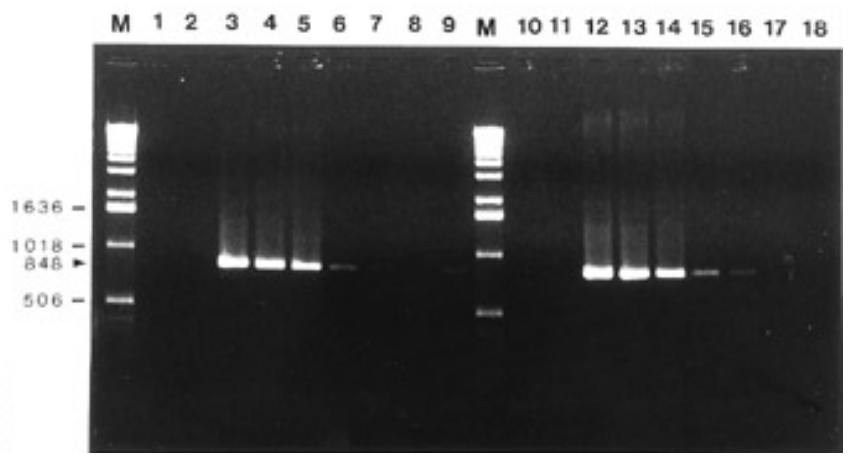

Fig. 4. Comparison of tube capture reverse transcription-polymerase chain reaction (RT-PCR) (lanes 1 to 9) and immunocapture RT-PCR (lanes 10 to 18) for the detection of cherry mottle leaf virus in cherry. Lane M, 1-kb DNA ladder; lanes 1, 2, 10, and 11, healthy controls (1:10 dilution); lanes 3 to 9 and lanes 12 to 18 , infected cherry sap diluted with healthy sap to obtain concentrations of $10^{-1}$, $10^{-2}, 10^{-3}, 10^{-4}, 10^{-5}, 10^{-6}$, and $10^{-7}$, respectively.

of CMLV in C. quinoa using total RNA extracts serially diluted. The dilution end point for detection by dot blot hybridization was $10^{-4}$ and for RT-PCR was $10^{-6}$.

Both IC/RT-PCR and TC/RT-PCR were effective for the detection of CMLV in herbaceous and woody tissue. The PCR product observed was $848 \mathrm{bp}$ in size, as expected. The sensitivities of IC/RT-PCR and TC/RT-PCR were compared using CMLV-infected Bing cherry serially diluted (10-fold) with healthy cherry sap. IC/RT-PCR was approximately 10 times more sensitive than TC/RT-PCR, with dilution end points of $10^{-5}$ and $10^{-4}$, respectively (Fig. 4).

Amino acid sequence alignment. The cDNA of CMLV was used to search against the nonredundant protein database at NCBI using BLAST-X. The best matches obtained for the amino acid sequence translated from the 848-bp amplified fragment of CMLV were with isolates of apple chlorotic leafspot virus (ACLSV) (Fig. 5). This fragment of CMLV is clearly a counterpart of a region of the RNA-dependent RNA polymerase of ACLSV-1 (24), ACLSV-2 (2), and ACLSV-3 (3). The percent amino acid identities observed were 27.3, 22.6, and 24.5\% for ACLSV-1, -2 , and -3 , respectively.

\section{DISCUSSION}

The oligonucleotide primers CML4A and CML13A specifically detected CMLV by RT-PCR analysis. These primers successfully detected all isolates of CMLV (in cherry and peach) tested, and a PCR product 848 bp in size was observed. When used to screen all available isolates of PMV, no reaction was observed, thus confirming the specificity of these primers. Amplification of this product was not observed with any of the healthy controls included in the study. RT-PCR using these primers is therefore a valuable tool for detecting CMLV and for distinguishing CMLV from PMV. This is important since these are serologically related viruses that cause distinct diseases and may infect similar hosts (9). Dot blot hybridization assays were used initially to identify clones that specifically bound to CMLV-associated RNA, and primer design was based on the sequences of these clones. This is therefore an effective process in designing primers that are specific for a particular target.

It was possible to consistently detect CMLV isolate Sa1162-21 in C. quinoa using a poly $(\mathrm{T})$ primer for the reverse transcription step in RT-PCR. This suggests that the CMLV genome is polyadenylated at the $3^{\prime}$ end.

In studies to assess the use of serological techniques for the detection of CMLV, the virus was detectable in leaf tissue, flower tissue, and fruit tissue (11). All attempts to detect the virus in dormant wood using serological techniques were unsuccessful. CMLV was, however, detected in leaf tissue and in bark tissue from dormant wood by RT-PCR and by IC/RT-PCR. This is important because it means that virus testing can be carried out at any time of year, and budwood received for CMLV testing need not be planted out or grown up to produce flowers or leaves. This will result in a significant saving of time, labor, and cost.

In this study, RT-PCR was 100 times more sensitive than dot blot hybridization for the detection of CMLV. This is consistent with the results of $\mathrm{Hu}$ et al. (5), who also found that RT-PCR was more sensitive than dot blot hybridization (using a ${ }^{32} \mathrm{P}$ labeled probe) for the detection of cucumber mosaic virus. IC/RT-PCR was found to be 10 times more sensitive than TC/RTPCR in this study. The virus was detectable in cherry and in $C$. quinoa using either procedure. The advantage of TC/RT-PCR is that no antibody is required. Useful antibodies against fruit tree viruses are often difficult to produce, and this technique may facilitate the use of multiplex-PCR in routine diagnosis.

Database searches with the translated 848-bp PCR product indicate that the best matches were with isolates of ACLSV, the type member of the Trichovirus group of viruses (14). The amino acids were 22.6 to $27.3 \%$ identical with amino acids of ACLSV in the region of the RNA-dependent RNA polymerase. This indicates that the primers CML4A and CML13A amplify a fragment in the region of the polymerase gene. This is usually a conserved region of the genome (3), but it seems that there are enough differences at the nucleotide level to facilitate the design of specific primers. Interestingly, comparisons of other preliminary sequence data of CMLV, including a poly(A) tail at the $3^{\prime}$ end of CMLV, suggest a much closer genomic relationship between CMLV and ACLSV than indicated by the region of the polymerase gene presented here. Further sequencing of the virus genome is now in progress in an attempt to definitively classify CMLV. 


\begin{tabular}{|c|c|c|}
\hline & 1 & 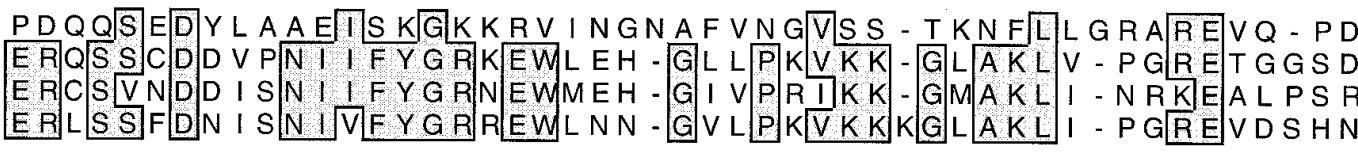 \\
\hline $\begin{array}{l}\text { MLV } \\
\text { CLSV-1 } \\
\text { CLSV-2 } \\
\text { CLSV-3 }\end{array}$ & $\begin{array}{l}50 \\
49 \\
49 \\
50\end{array}$ & 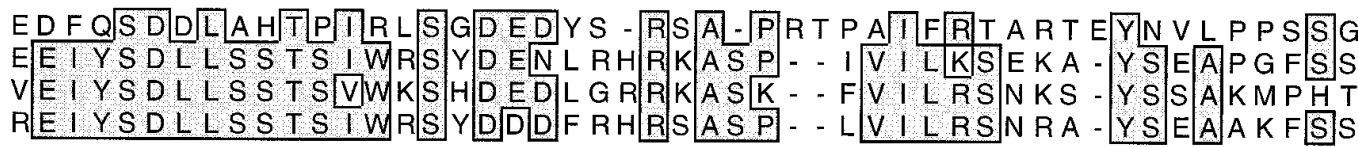 \\
\hline $\begin{array}{l}V-1 \\
V-2 \\
V-3\end{array}$ & $\begin{array}{l}99 \\
97 \\
97 \\
98\end{array}$ & 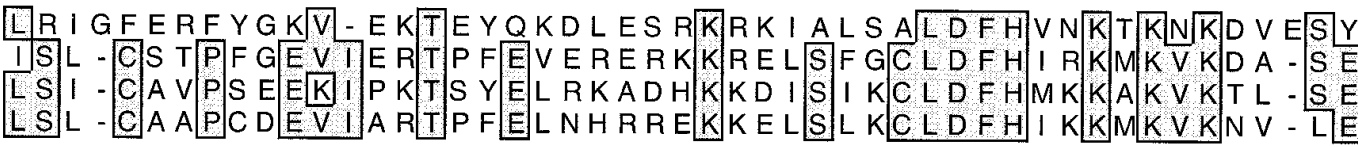 \\
\hline $\begin{array}{l}\text { MLV } \\
\text { LLSV-1 } \\
\text { CLSV-2 } \\
\text { LLSV-3 }\end{array}$ & 6 & 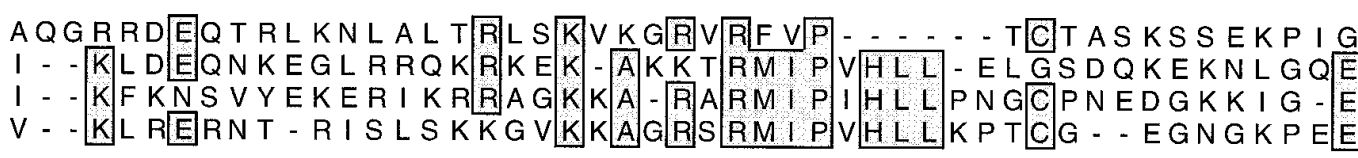 \\
\hline $\begin{array}{l}\text { CMLV } \\
\text { ACLSV-1 } \\
\text { ACLSV-2 } \\
\text { ACLSV-3 }\end{array}$ & $\begin{array}{l}193 \\
193\end{array}$ & 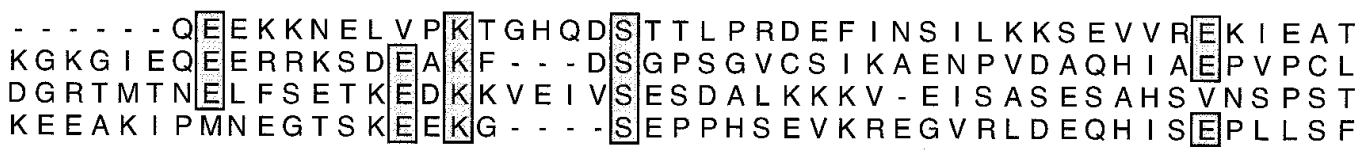 \\
\hline $\begin{array}{l}\text { MLV } \\
\text { CLSV-1 } \\
\text { CLSV-2 }\end{array}$ & 40 & 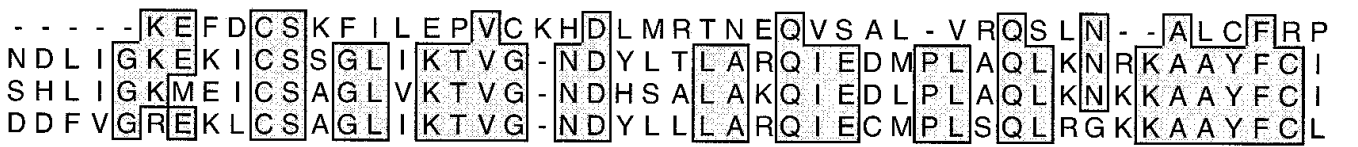 \\
\hline
\end{tabular}

Fig. 5. Amino acid sequence alignment in the region of the polymerase chain reaction (PCR) amplified fragment of cherry mottle leaf virus was obtained by searching the non-redundant database of the National Center for Biotechnology Information using BLAST-X. Apple chlorotic leaf spot virus (ACLSV) provided the best match. ACLSV-1, -2, and -3 represent accession numbers 1710717, 2104793, and 137259, respectively. Residues are boxed if three or more amino acids are identical.

\section{ACKNOWLEDGMENTS}

This study was supported in part by NATO Collaborative Research Grant No. CRG 950665 to D. James and W. Jelkmann, and an NSERC Operating Grant to C. Upton. We would like to thank T. Li, L. Parish, G. Oldfield, and J. Uyemoto for providing samples of CMLV; and H. J. Larsen for samples of PMV.

\section{LITERATURE CITED}

1. Devereux, J., Haeberli, P., and Smithies, O. 1984. A comprehensive set of sequence analysis programs for the VAX. Nucleic Acids Res. 12:387-395.

2. German, S., Bergey, B., Delbos, R. P., Candresse, T., and Dunez, J. 1997. Complete nucleotide sequence of the genome of a severe cherry isolate of apple chlorotic leaf spot trichovirus (ACLSV). Arch. Virol. 142:833-841.

3. German, S., Candresse, T., Lanneau, M., Huet, J. C., Pernollet, J. C., and Dunez, J. 1990. Nucleotide sequence and genomic organization of apple chlorotic leaf spot closterovirus. Virology 179(1):104-112.

4. Grunstein, M., and Hogness, D. S. 1975. Colony hybridization: A method for the isolation of cloned DNAs that contain a specific gene. Proc. Natl. Acad. Sci. (USA) 72:39613965.

5. Hu, J. S., Li, H. P., Barry, K., Wang, M., and Jordan, R. 1995. Comparison of dot blot, ELISA, and RT-PCR assays for detection of two cucumber mosaic virus isolates infecting banana in Hawaii. Plant Dis. 79:902-906.

6. James, D. 1992. Partial characterization of a closterovirus-like particle transmitted from cherry (Prunus avium) infected with several viral diseases. Acta Hortic. 308:39-44.

7. James, D. 1994. Cherry mottle leaf: The fulfillment of Koch's postulates. Pages 17-20 in: Proceedings of the International Symposium: Rose Rosette and other Eriophyid Mite- transmitted Plant Disease Agents of Uncertain Etiology. A. H. Epstein and J. H. Hill, eds. Iowa State University, Ames.

8. James, D., and Howell, W. E. 1993. Comparison of cherry mottle leaf virus and a virus associated with peach mosaic disease. (Abstr. 17.1.20) Int. Congr. Plant Pathol. 6th, Montreal.

9. James, D., and Howell, W. E. 1998. Isolation and partial characterization of a filamentous virus associated with peach mosaic disease. Plant Dis. 82:909-913.

10. James, D., and Mukerji, S. 1993. Mechanical transmission, identification, and characterization of a virus associated with mottle leaf in cherry. Plant Dis. 77:271-275.

11. James, D., and Mukerji, S. 1996. Comparison of ELISA and immunoblotting techniques for the detection of cherry mottle leaf virus. Ann. Appl. Biol. 129:13-23.

12. Jelkmann, W., Martin, R. R., and Maiss, E. 1989. Cloning of four plant viruses from small quantities of double-stranded RNA. Phytopathology 79:1250-1253.

13. Keifer, H. H., and Wilson, N. S. 1955. A new species of eriophyid mite responsible for the vection of peach mosaic virus. Bull. Calif. Dep. Agric. 44:145-146.

14. Martelli, G. P., Candresse, T., and Namba, S. 1993. Trichovirus, a new genus of plant viruses. Arch. Virol. 134:451-455.

15. Miller, S. A., and Martin, R. R. 1988. Molecular diagnosis of plant disease. Annu. Rev. Phytopathol. 26:409-432.

16. Morris, T. J., and Dodds, J. A. 1979. Isolation and analysis of double-stranded RNA from virus-infected plant and fungal tissue. Phytopathology 69:854-858.

17. Oldfield, G. N. 1970. Mite transmission of plant viruses. Annu. Rev. Entomol. 15:343380 .

18. Oldfield, G. N., Creamer, R., Gispert, C.,
Osorio, F., Rodriguez, R., and Perring, T. M. 1995. Incidence and distribution of peach mosaic and its vector, Eriophyes insidiosus (Acari:Eriophyidae) in Mexico. Plant Dis. 79:186-189.

19. Olmos, A., Cambra, M., Dasi, M. A., Candresse, T., Esteban, O., Gorris, M. T., and Asensio, M. 1997. Simultaneous detection and typing of plum pox potyvirus (PPV) isolates by heminested-PCR and PCR-ELISA. J. Virol. Methods 68:127-137.

20. Omunyin, M. E., Hill, J. H., and Miller, W. A. 1996. Use of unique RNA sequence-specific oligonucleotide primers for RT-PCR to detect and differentiate soybean mosaic virus strains. Plant Dis. 80:1170-1174.

21. Poggi Pollini, C., Giunchedi, L., and Bissani, R. 1997. Specific detection of D- and M-isolates of plum pox virus by immunoenzymatic determination of PCR products. J. Virol Methods 67:127-133.

22. Rizos, H., Gunn, L. V., Pares, R. D., and Gillings, M. R. 1992. Differentiation of cucumber mosaic virus isolates using polymerase chain reaction. J. Gen. Virol. 73:2099-2103.

23. Sambrook, J., Fritsch, E. J., and Maniatis, T. 1989. Molecular Cloning: A Laboratory Manual. 2nd ed. Cold Spring Harbor Laboratory, Cold Spring Harbor, NY.

24. Sato, K., Yoshikawa, N., and Takahashi, T. 1993. Complete nucleotide sequence of the genome of an apple isolate of apple chlorotic leaf spot virus. J. Gen. Virol. 74:1927-1931.

25. Welnicki, M., and Hiruki, C. 1992. Highly sensitive digoxigenin-labelled DNA probe for the detection of potato spindle tuber viroid. J. Virol. Methods 39:91-99.

26. Wetzel, T., Candresse, T., Ravelonandro, M., and Dunez, J. 1991. A polymerase chain reaction assay adapted to plum pox potyvirus detection. J. Virol. Methods 33:355-365. 